\title{
Five-year disease-free survival among stage II-IV breast cancer patients receiving FAC and AC chemotherapy in phase II clinical trials of Panagen
}

Anastasia S. Proskurina ${ }^{1 \dagger}$, Tatiana S. Gvozdeva ${ }^{2+}$, Ekaterina A. Potter ${ }^{1}$, Evgenia V. Dolgova', Konstantin E. Orishchenko ${ }^{1}$, Valeriy P. Nikolin ${ }^{1}$, Nelly A. Popova ${ }^{1,3}$, Sergey V. Sidorov ${ }^{3,4}$, Elena R. Chernykh ${ }^{5}$, Alexandr A. Ostanin ${ }^{5}$, Olga Y. Leplina ${ }^{5}$, Victoria V. Dvornichenko6,7, Dmitriy M. Ponomarenko $0^{6,7}$, Galina S. Soldatova ${ }^{3,8}$, Nikolay A. Varaksin ${ }^{9}$, Tatiana G. Ryabicheva ${ }^{9}$, Peter N. Uchakin ${ }^{10}$, Vladimir A. Rogachev Mikhail A. Shurdov ${ }^{11}$ and Sergey S. Bogachev ${ }^{1 *}$

\begin{abstract}
Background: We report on the results of a phase II clinical trial of Panagen (tablet form of fragmented human DNA preparation) in breast cancer patients (placebo group $n=23$, Panagen $n=57$ ). Panagen was administered as an adjuvant leukoprotective agent in FAC and AC chemotherapy regimens. Pre-clinical studies clearly indicate that Panagen acts by activating dendritic cells and induces the development of adaptive anticancer immune response.

Methods: We analyzed 5-year disease-free survival of patients recruited into the trial.

Results: Five-year disease-free survival in the placebo group was $40 \%(n=15)$, compared with the Panagen arm $53 \%(n=51)$. Among stage III patients, disease-free survival was 25 and $52 \%$ for placebo $(n=8)$ and Panagen $(n=25)$ groups, respectively. Disease-free survival of patients with IIIB $+C$ stage was as follows: placebo $(n=6)-17 \%$ vs Panagen $(n=18)-50 \%$.

Conclusions: Disease-free survival rate (17\%) of patients with IIIB + C stage breast cancer receiving standard of care therapy is within the global range. Patients who additionally received Panagen demonstrate a significantly improved disease-free survival rate of $50 \%$. This confirms anticancer activity of Panagen.
\end{abstract}

Trial registration: ClinicalTrials.gov NCT02115984 from 04/07/2014.

Keywords: Breast cancer, FAC chemotherapy, AC chemotherapy, Disease-free survival, dsDNA, CD8 + perforin + T cells Abbreviations: AC chemotherapy, Chemotherapy including doxorubicin and cyclophosphamide; DFS, Disease-free survival; dsDNA, Double-stranded DNA; T-reg, CD25+ CD127- T-regulatory lymphocyte; FAC chemotherapy, Chemotherapy including 5-fluorouracil, doxorubicin and cyclophosphamide

\footnotetext{
* Correspondence: labmolbiol@mail.ru

${ }^{\dagger}$ Equal contributors

${ }^{1}$ Institute of Cytology and Genetics, Siberian Branch of the Russian Academy

of Sciences, 10 Lavrentieva Ave, Novosibirsk 630090, Russia

Full list of author information is available at the end of the article
} 


\section{Background}

Breast cancer along with skin, lung, colorectal and stomach cancer make up the top five most common malignancies. It is a leading cause of cancer-related mortality among women and therefore has a high social impact [1-3]. Positive prognosis in breast cancer is correlated with early diagnosis and proper choice of systemic therapy. Presently, the conventional breast cancer therapies include mastectomy or radical resection, adjuvant chemotherapy, hormonal therapy, and targeted therapy (whenever appropriate, such as in HER2/neu-positive tumors) (reviewed in [4]). Given that breast cancer is a systemic disease, cytoreductive chemotherapy is essential for the successful treatment.

In breast cancer, chemotherapy combines alkylating activity of a cytostatic drug (cyclophosphamide), anthracycline (doxorubicin, farmorubicin, mitoxantrone) and antimetabolite (5-fluorouracil, ftorafur, gemcitabine, xeloda, metotrexate). Treatment schemes may also include Vinca alkaloids (vincristine, vinblastine, navelbine), taxanes (taxol, taxotere) and platinum compounds (cisplatin, carboplatin). Two basic schemes remain at the mainstream of breast cancer therapy: FAC (a combination of 5-fluorouracil, doxorubicin and cyclophosphamide) and AC (doxorubicin and cyclophosphamide). To boost the efficiency, these can be further modified by introducing additional components or substituting the basic components with other drugs [5-10].

As much as 1.5 million new cases of breast cancer are diagnosed worldwide each year, with a lethal outcome for about 400 thousand people. The current gold standard for assessing the therapeutic efficacy in breast cancer patients is 5-year disease-free survival (hereafter referred to as DFS), i.e. the percentage of patients that are alive 5 years after their primary treatment without any signs or symptoms of that cancer. Whereas stage II breast cancer is curable, with DFS ranging 75-90 \%, and stage IV breast cancer has a poor prognosis with DFS of 0-10\%, efficacy of the therapy is best established by assessing DFS of stage III patients.

From the clinical perspective, locally disseminated breast cancer (stage III) has DFS rate of 10-50 \% regardless of the frontline therapy received by the patient $[4,6$, $11,12]$. Stage III breast cancer can be further subdivided into three subgroups IIIA, B and C, according to the extent of disease progression $[6,12]$. Stages IIIB and IIIC consistently have a poorer prognosis compared to IIIA, which is mirrored by DFS in these patient groups below 30\% [12].

Our previous report [13] summarizes the results of phase II clinical trial of Panagen with major emphasis on the analysis of Panagen's leukoprotective properties. The data obtained in the study indicate that inclusion of Panagen into standard chemotherapy regimens leads to protection of white blood cell lineage from detrimental effects of three consecutive rounds of FAC or AC. Notably, combination of Panagen with either FAC or AC therapies results in fewer grade I-IV neutropenias and in the maintenance of pre-therapeutic activity of innate anticancer immunity cells.

It was first reported in 2001 that genomic doublestranded DNA as well as CpG oligodeoxynucleotides can activate antigen-presenting properties of dendritic cells and that it boosts the developing adaptive immune response [14]. In later studies, the major focus was on CpG DNA as a structurally homogeneous molecule with a therapeutic potential $[15,16]$. In contrast, genomic double-stranded DNA received far less attention in this respect due to the issues in standardization of doublestranded DNA preparations. Our group, however, continued to explore and analyze how fragmented human double-stranded DNA influences different cell types and cell populations, using mouse models and in clinical trials.

Our earlier studies focused on unraveling how double-stranded DNA-based medications may interact with the body cellular machinery. These studies demonstrated that the primary cell targets of fragmented exogenous double-stranded DNA are peripheral blood mononuclear cells, dendritic cells, as well as stem cells of various origin [17-19]. It is this interaction of Panagen with peripheral blood mononuclear and dendritic cells that mediates its leukoprotective activity and the development of adaptive anticancer immunity [20, 21]. With this in mind, when performing stage II clinical trial, we designed and implemented an additional experimental protocol that was supposed to inform us more on the development of adaptive anticancer immune response in patients recruited to the study. We showed that in the patient group receiving Panagen, there is a statistically significant increase in the percentage of $\mathrm{CD} 8+$ perforin + cytotoxic $\mathrm{T}$ cells in peripheral blood, - importantly, it is this cell type that is known to play one of the major roles in adaptive immunity.

Early experiments showed pronounced activation of dendritic cells upon CpG DNA administration. This effect was mediated by the interaction of the ligand and TLR9 in dendritic cells [14-16]. Subsequently, several types of CpG oligodeoxynucleotides were tested as anticancer agents in the context of breast cancer [22, 23]. In contrast to our approach, wherein tablet form of Panagen was used per os and the active substance primarily targeted the mucosal immune cells, all the CpG-based medications were delivered as intravenous, intramuscular or subcutaneous injections. Data obtained in phase I and II clinical trials indicated that these medications were highly toxic to the trial participants and caused a number of serious side effects. For this reason, 
Table 1 Patient data during the clinical trial of Panagen

\begin{tabular}{|c|c|c|c|c|c|c|c|}
\hline $\begin{array}{l}\text { Patient } \\
\text { number }\end{array}$ & $\begin{array}{l}\text { Breast cancer } \\
\text { stage }\end{array}$ & & 1 year & 1.5 years & 2 years & $3-4$ years & 5 years \\
\hline \multicolumn{8}{|c|}{ FAC chemotherapy + Placebo } \\
\hline $01-03$ & T2N1M0 & $\| B$ & remission & remission & remission & remission & remission \\
\hline $01-08$ & T2NOMO & $\| \mathrm{A}$ & remission & remission & remission & remission & remission \\
\hline $01-12$ & T4N3M1 & IV & remission & remission & disease progression & deceased & - \\
\hline $01-16$ & T4N2MO & $\| I B$ & remission & remission & $\begin{array}{l}\text { deceased } \\
\text { (cause of death } \\
\text { is not cancer) }\end{array}$ & - & - \\
\hline $01-23$ & T4NOMO & $\| \mathrm{II}$ & remission & remission & disease progression & no data & no data \\
\hline $02-07$ & T4N2M0 & $\| I B$ & deceased & - & - & - & - \\
\hline $02-12^{\mathrm{a}}$ & $\mathrm{T} 2 \mathrm{~N} 2 \mathrm{MO}$ & $\| I I A$ & remission & remission & no data & no data & no data \\
\hline $02-13$ & T4N3M0/1 & IV & therapy continues & $\begin{array}{l}\text { disease progression, } \\
\text { lung metastases }\end{array}$ & deceased & - & - \\
\hline $02-17$ & T2N1M0 & $\| B$ & remission & remission & remission & remission & remission \\
\hline \multicolumn{8}{|c|}{ AC chemotherapy + Placebo } \\
\hline $02-23^{\mathrm{a}}$ & $\mathrm{T} 2 \mathrm{~N} 1 \mathrm{MO} / 1$ & IV & $\begin{array}{l}\text { disease progression, lymph } \\
\text { node metastases before the } \\
\text { study + bone metastases }\end{array}$ & deceased & - & - & - \\
\hline $02-32$ & T4NxMO & $\| I B$ & remission & remission & remission & remission & no data \\
\hline $02-34$ & T4N2MO & $\| I B$ & $\begin{array}{l}\text { disease progression, } \\
\text { metastases to bones, } \\
\text { lungs, and soft tissues } \\
\text { of the chest wall }\end{array}$ & no data & no data & no data & no data \\
\hline $02-35^{\mathrm{a}}$ & T4NxMO & $\| \mid \mathrm{B}$ & remission & no data & no data & deceased & - \\
\hline $02-37^{\mathrm{a}}$ & T4NOMO & $\| \mathrm{II}$ & $\begin{array}{l}\text { disease progression, brain, } \\
\text { lungs, liver and bone } \\
\text { metastases }\end{array}$ & deceased & - & - & - \\
\hline $02-38$ & T2N2M0 & $\| \mathrm{A}$ & no data & deceased & - & - & - \\
\hline $02-41$ & T1N1M0 & $\| \mathrm{A}$ & remission & remission & remission & remission & no data \\
\hline \multicolumn{8}{|c|}{ FAC chemotherapy + Panagen } \\
\hline $01-01$ & T1N2M0 & $\| \mathrm{A}$ & remission & remission & remission & disease progression & no data \\
\hline $01-02$ & T1N2M0 & $\| I A$ & remission & remission & remission & disease progression & no data \\
\hline $01-04$ & T4N2M1 & IV & remission & remission & remission & deceased & - \\
\hline 01-05 & T2N1M0 & $\| B$ & remission & deceased & - & - & - \\
\hline $01-06$ & T4N1M0 & $\| I B$ & remission & remission & remission & remission & remission \\
\hline $01-07$ & T3NOMO & $\| B$ & remission & remission & remission & remission & remission \\
\hline 01-09 & T2N2M0 & $\| I A$ & remission & remission & remission & no data & no data \\
\hline $01-10$ & T4N3M0 & $\| I I C$ & remission & remission & remission & remission & no data \\
\hline $01-11$ & T2N1M0 & $\| B$ & remission & remission & remission & remission & no data \\
\hline $01-13$ & T4N3M0 & $\| I C$ & remission & remission & remission & remission & remission \\
\hline $01-14$ & T4N2MO & $\| \mid \mathrm{B}$ & remission & remission & remission & disease progression & deceased \\
\hline $01-15$ & T2N2M0 & $\| \mathrm{A}$ & remission & remission & remission & remission & remission \\
\hline $01-17$ & T2N1M0 & $\| B$ & remission & remission & remission & no data & no data \\
\hline 01-18 & T4N1M0 & $\| \mid \mathrm{B}$ & disease progression & no data & no data & no data & alive \\
\hline 01-19 & T4N1M0 & $\| \mathrm{B}$ & remission & remission & remission & deceased & - \\
\hline $01-20$ & T2NOMO & $\| \mathrm{A}$ & remission & remission & remission & remission & remission \\
\hline $01-21$ & T4N3M0 & IIIC & disease progression & no data & no data & alive & alive \\
\hline $01-22$ & T4N1M1 & IV & remission & remission & remission & disease progression & deceased \\
\hline
\end{tabular}


Table 1 Patient data during the clinical trial of Panagen (Continued)

\begin{tabular}{|c|c|c|c|c|c|c|c|}
\hline $02-01$ & T4NxM0 & IIIB & no data & no data & no data & $\begin{array}{l}\text { disease progression, } \\
\text { tumor disintegration, } \\
\text { multiple metastases } \\
\text { in lungs }\end{array}$ & deceased \\
\hline $02-02$ & T2NOMO & $\| \mathrm{A}$ & remission & remission & remission & no data & no data \\
\hline 02-03 & T1N1M0 & $\| \mathrm{A}$ & remission & remission & remission & $\begin{array}{l}\text { disease progression, } \\
\text { Th11 metastases }\end{array}$ & no data \\
\hline 02-04 & T3N2M1 & IV & deceased & - & - & - & - \\
\hline $02-05$ & T4N1M0 & IIIB & remission & remission & remission & remission & remission \\
\hline $02-06$ & T4NxM1 & IV & deceased & - & - & - & - \\
\hline 02-08 & T4N1M0 & IIIB & remission & remission & remission & $\begin{array}{l}\text { disease progression, } \\
\text { lung, pleura and liver } \\
\text { metastases }\end{array}$ & no data \\
\hline 02-09 & T1N1M0/1 & IV & $\begin{array}{l}\text { disease progression, bone } \\
\text { metastases observed during } \\
\text { the } 1^{\text {st }} C T \text { round }\end{array}$ & alive & alive & deceased & - \\
\hline $02-10$ & T1N1M0 & $\| \mathrm{A}$ & remission & remission & remission & remission & remission \\
\hline $02-11^{\mathrm{a}}$ & T2N1M0 & $\| \mathrm{B}$ & remission & remission & remission & remission & remission \\
\hline $02-14$ & T2N2M0dex T4N1MOsin & $\| \mathrm{II}$ & remission & remission & remission & remission & remission \\
\hline $02-15$ & T3N2M0 & $\| \mathrm{A}$ & remission & remission & remission & remission & remission \\
\hline $02-16^{\mathrm{a}}$ & T4NxMO & $\| \mathrm{B}$ & remission & $\begin{array}{l}\text { disease progression, } \\
\text { metastases in the skin } \\
\text { region adjacent to } \\
\text { surgery scar }\end{array}$ & partial regression & deceased & - \\
\hline $02-18^{a}$ & $\mathrm{~T} 4 \mathrm{~N} \times \mathrm{MO}$ & $\| I B$ & remission & remission & remission & remission & remission \\
\hline \multicolumn{8}{|c|}{ AC chemotherapy + Panagen } \\
\hline $02-20$ & T2N1M0 & $\| B$ & remission & remission & remission & $\begin{array}{l}\text { disease progression, } \\
\text { bone metastases }\end{array}$ & no data \\
\hline $02-21$ & T2NOMO & $\| \mathrm{A}$ & remission & remission & remission & remission & no data \\
\hline $02-22^{\mathrm{a}}$ & T2N1M0 & $\| B$ & remission & remission & remission & remission & no data \\
\hline $02-24$ & T2N1M0 & $\| B$ & remission & remission & remission & remission & no data \\
\hline $02-25^{\mathrm{a}}$ & $\mathrm{T} 2 \mathrm{~N} 2 \mathrm{MO}$ & IIIA & remission & remission & remission & remission & no data \\
\hline $02-26$ & T1N1M0 & $\| \mathrm{A}$ & remission & remission & remission & remission & no data \\
\hline $02-27$ & T1N2M0 & $\| I A$ & remission & remission & $\begin{array}{l}\text { disease } \\
\text { progression, } \\
\text { bone metastases }\end{array}$ & no data & no data \\
\hline $02-28^{\mathrm{a}}$ & T2N1M0 & $\| \mathrm{B}$ & remission & remission & $\begin{array}{l}\text { disease } \\
\text { progression, } \\
\text { bone and lung } \\
\text { metastases }\end{array}$ & no data & no data \\
\hline $02-29$ & T2NOMO & $\| \mathrm{A}$ & remission & remission & no data & deceased & - \\
\hline $02-30$ & T2NxMO & $\|$ & remission & remission & remission & remission & no data \\
\hline $02-31$ & T2N1M0/1 & IV & $\begin{array}{l}\text { disease progression, } \\
\text { lung metastases observed } \\
1 \text { month following } \\
\text { completion of the therapy }\end{array}$ & no data & no data & no data & no data \\
\hline $02-33^{\mathrm{a}}$ & T2N3M0 & IIIC & remission & remission & remission & remission & no data \\
\hline $02-36$ & T4NxM0dex T2NxMOsin & IIIB & treatment continues & treatment continues & no data & no data & no data \\
\hline 02-39 & T2N3M0 & IIIC & remission & remission & relapse & no data & no data \\
\hline $02-40^{a}$ & T2N1M0 & $\| B$ & remission & no data & no data & no data & no data \\
\hline $02-42^{a}$ & T1N3M0 & $\| I I C$ & remission & remission & remission & remission & no data \\
\hline $02-43$ & T3NOMO & $\| B$ & remission & remission & remission & remission & no data \\
\hline
\end{tabular}


Table 1 Patient data during the clinical trial of Panagen (Continued)

\begin{tabular}{|c|c|c|c|c|c|c|c|}
\hline $02-44^{a}$ & T1N1M0/1 & IV & $\begin{array}{l}\text { disease progression, } \\
\text { bone metastases } \\
\text { observed after the } 2^{\text {nd }} \\
\text { CT round }\end{array}$ & no data & no data & no data & no data \\
\hline $02-45^{\mathrm{a}}$ & T4N1M0 & $\| \mathrm{IIB}$ & remission & remission & $\begin{array}{l}\text { disease } \\
\text { progression, } \\
\text { pleural } \\
\text { metastases }\end{array}$ & no data & no data \\
\hline
\end{tabular}

Note: ${ }^{a}$ - tamoxifen treatment. CT chemotherapy. Patients who progressed or died are shown in boldface. Cause of death in all cases is breast cancer, except patient $01-16$. Patient 01-16, whose cause of death was not cancer, didn't taken into account further

all the clinical trials of these drugs as anticancer agents are currently put on hold. Instead, the interest in these drugs has shifted to their possible use as adjuvants and to designing the CpG-based medications that are less toxic $[22,23]$. Our phase II clinical trial of Panagen was based on the premise that activation of dendritic cells resident in the intestinal mucosa (using gastro-resistant tablets) should be comparable to the injection form of CpG-based preparations in terms of inducing adaptive immunity, yet it should have a favorable toxicity profile.

In the present report, we analyze the efficiency of Panagen as an adjuvant anticancer medication, given that it can enhance personalized anticancer adaptive immunity [13]. Specifically, we calculated and compared 5 -year DFS of patients from experimental and placebo groups. This analysis also helped determine the breast cancer stage when combined use of Panagen and the standard chemotherapy (FAC or $\mathrm{AC}$ ) results in the best response rate.

\section{Methods}

Phase II clinical trial of preparation Panagen was approved by the Ministry of Health and Social Development of the Russian Federation (No. 47 of 03/12/2010) as well as by the local ethics committees at the Irkutsk Regional Oncology Dispensary and the Novosibirsk Municipal Hospital No 1, where clinical trials were subsequently performed. The studies were carried out in compliance with the World Medical Association Declaration of Helsinki. Written informed consent to participate in the study was obtained from each of the patients, which specified open publication of the results

Table 2 Five-year disease-free survival

\begin{tabular}{|c|c|c|c|c|c|c|c|}
\hline & \multicolumn{3}{|c|}{ Chemotherapy + Placebo } & \multicolumn{3}{|c|}{ Chemotherapy + Panagen } & \multirow{2}{*}{$\begin{array}{l}{[38]} \\
\text { Survival, \% }\end{array}$} \\
\hline & Patients & $\begin{array}{l}\text { Survived } \\
\text { patients }\end{array}$ & $\%$ & Patients & $\begin{array}{l}\text { Survived } \\
\text { patients }\end{array}$ & $\%$ & \\
\hline I & & & & & & & 76.7 \\
\hline$\|$ & 4 & 4 & 100 & 19 & 14 & 74 & \\
\hline III & 8 & 2 & 25 & 25 & 13 & 52 & \\
\hline IV & 3 & 0 & 0 & 7 & 0 & 0 & \\
\hline Total & 15 & 6 & 40 & 51 & 27 & 53 & \\
\hline
\end{tabular}

presented as reports or otherwise. All patients were also insured.

Other details of the clinical trial protocol can be found in [13].

\section{Results}

Overall analysis of 5-year survival of patients recruited to the phase II clinical trial of Panagen

Patients recruited to the clinical trials of Panagen were followed-up for 5 years after the therapy. Overall, of 80 stage II-IV breast cancer patients 13 were excluded from the study for various reasons. Thus, the Panagen and the placebo arms of the trial included 51 and 16 patients, respectively. All the patients completed the full course of FAC or AC therapies followed by tamoxifen therapy, whenever their tumors were classified as hormonedependent. By the end of the 5-year period data of survival were collected (Table 1).

We analyzed 5-year overall survival and DFS of patients recruited to the study. These parameters were calculated separately for disease stages. Additionally, we estimated the correlation between 5-year DFS and the immune status of FAC-treated patients.

\section{Five-year overall survival and DFS of patients in Panagen trial}

Our analysis suggests that 5-year DFS of patients from the placebo group was $40 \%$, whereas for those receiving Panagen it was $53 \%$ (Table 2).

Of 8 stage III placebo-group patients, 6 had IIIB or IIIC breast cancer. The same substages were diagnosed for 18 patients out of 25 stage III breast cancer patients in the Panagen-group. Five-year DFS of IIIB/IIIC patients in the placebo group was $17 \%$, compared to $50 \%$ observed in the Panagen group (Table 3).

Next, survival of patients in our trial was compared to the literature data. Both 5-year DFS and overall survival are consistent with the current literature rates (Tables 2 and 4). Overall survival of substage IIIA and IIIB breast cancer patients in the placebo cohort was comparable to the figures referenced in the literature (Table 5). Notably, in the Panagen arm, overall survival of stage III patients was significantly higher than that in the 
Table 3 Five-year disease-free survival for stage III breast cancer

\begin{tabular}{|c|c|c|c|c|c|c|c|c|c|}
\hline & Chemoth & $y+$ Placebo & & & Chemoth & + Panagen & & & {$[25]$} \\
\hline & Patients & Survived patients & $\%$ & & Patients & Survived patients & $\%$ & & Survival, \% \\
\hline IIIA & 2 & 1 & & 50 & 7 & 4 & & 57 & 47 \\
\hline IIIB & 6 & 1 & 17 & 17 & 12 & 5 & 42 & 50 & \\
\hline IIIC & 0 & - & - & & 6 & 4 & 67 & & \\
\hline Stage III, total & 8 & 2 & & 25 & 25 & 13 & & 52 & \\
\hline
\end{tabular}

literature. Namely, for substage IIIA patients the numbers were $100 \%$ (Panagen) vs $66.7 \%$ [24], for stage IIIB, overall survival was $67 \%$ (Panagen) vs $41 \%$ [24], and for IIIA and IIIB substages the combined overall survival was $79 \%$ (Panagen) vs $57 \%$ [25]. Importantly, overall survival of substage IIIC patients on Panagen was $100 \%$. This data of 5-year overall survival for stage III show a significant contribution of Panagen to the treatment efficiency. Differences in the 5-year DFS also support the contribution of Panagen to favorable outcome (Table 3).

\section{Comparison of immune status of patients on FAC + Placebo vs FAC + Panagen regimens}

Several parameters informative of the immune status of the patients were measured in the additional protocol of the clinical study. These include changes in cell counts for CD123+ (plasmacytoid dendritic cells), CD11+ (myeloid dendritic cells), CD25+ CD127- (T-regs), CD8 + perforin + (cytotoxic T-cells). Higher counts of CD123+, CD11+ and CD8 + perforin + cells in patients would be interpreted as activated adaptive immunity. Decreased T-reg counts are generally indicative of the reduced immunosuppression by the tumor. Table 6 summarizes these parameters in FAC-treated patients from Novosibirsk Municipal Hospital No 1. Further, these parameters have been correlated with survival. Patients with stage IV cancer were omitted from the analysis, as our data suggested Panagen provided little advantage to this patient group.

The figures were available for 2 Placebo-treated patients with stage IIIA and IIIB disease (Table 6). The surviving patient had a pronounced trend for gradually improving adaptive immunity whereas T-reg population was significantly reduced. The other patient, who did not survive the 5-year period, had high T-reg counts in one of the tests. Adaptive immunity scores generally remained high.

In the Panagen-treated group, three patients out of four remained disease-free 5 years after the therapy. In these surviving patients, the parameters characteristic of the stimulated adaptive immunity were greatly improved. T-reg population was either slightly above the initial level or was reduced during the course of 3 chemotherapy rounds. The patient who did not survive showed no response to the treatments, as assayed by plasmacytoid and myeloid dendritic cells and activated $\mathrm{T}$ cell counts. This was accompanied with increasing numbers of T-regs, compared to the initial values observed in that patient.

No correlation between survival and cell counts was evident for stage III patients receiving Panagen. However, we must note that the two patients who deceased displayed 2-3 times more T-regs relatively to the initial levels, which was accompanied by an otherwise activated adaptive immunity profile. In the surviving patients, the percentage of T-regs either progressively decreased during the study or was not high at the baseline. In all but one cases, adaptive immunity appeared activated.

It is widely known that cyclophosphamide is not merely a cytotoxic drug but also has an immunomodulatory activity. It induces abortive mobilization of CD34 hematopoietic progenitors [26-28], it stimulates proliferation of dendritic cell progenitors in the bone marrow, which results in the increased dendritic cell counts in peripheral blood and is coincident with the unfolding adaptive immune response [29]. It generally increases the immune response by maintaining the balance of dendritic cell subpopulations [30], and finally it either abrogates or inhibits the functionality of T-regs [31, 32]. In this context, it is difficult to

Table 4 Five-year overall survival

\begin{tabular}{|c|c|c|c|c|c|c|c|c|c|}
\hline & \multicolumn{3}{|c|}{ Chemotherapy + Placebo } & \multicolumn{3}{|c|}{ Chemotherapy + Panagen } & \multirow{2}{*}{$\begin{array}{l}{[38]} \\
\text { Survival, \% }\end{array}$} & \multirow{2}{*}{$\begin{array}{l}{[24]} \\
\text { Survival, \% }\end{array}$} & \multirow{2}{*}{$\begin{array}{l}{[39]} \\
\text { Survival, \% }\end{array}$} \\
\hline & Patients & Survived patients & $\%$ & Patients & Survived patients & $\%$ & & & \\
\hline । & & & & & & & 100.0 & 92.1 & \\
\hline$\|$ & 4 & 4 & 100 & 19 & 17 & 89 & 89.0 & 81.8 & \\
\hline III & 8 & 4 & 50 & 25 & 21 & 84 & 80.8 & 58.0 & \\
\hline IV & 3 & 0 & 0 & 7 & 2 & 29 & & & \\
\hline Total & 15 & 8 & 53 & 51 & 40 & 78 & & & $40-70$ \\
\hline
\end{tabular}


Table 5 Five-year overall survival for stage III breast cancer

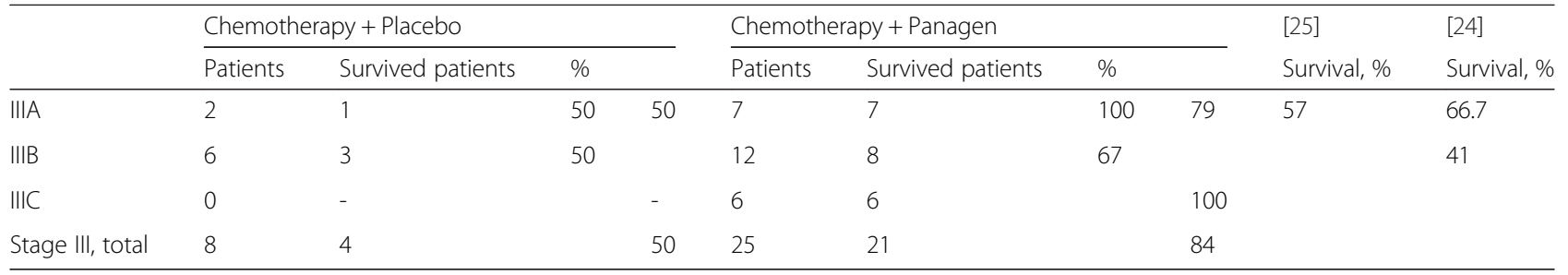

unambiguously establish the direct contribution of Panagen into changes in the parameters measured in our patients.

Taken together, our data indicate that the following combination of parameters may have a positive prognostic value: high percentage of $\mathrm{CD} 8+$ perforin $+\mathrm{T}$-cells, high percentage of $\mathrm{CD} 123+$ and/or CD11+ dendritic cells and low or decreasing T-reg counts.

\section{Discussion}

Clinical evidence indicates that upon proper therapy, stage IIIB breast cancer is treatable and shows a DFS rate of $10-40 \%$. DFS is below $10 \%$ for stage IIIC. The sample size of patients in our study was relatively small, and so we grouped IIIB and IIIC stage breast cancer patients into one dataset for statistical analysis. DFS rate (17\%) of patients receiving standard of care therapy is within the global range. Patients who additionally received Panagen demonstrate a significantly higher DFS of $50 \%$.

Thus, the following mechanism of the anticancer activity of Panagen emerges from the above data and the pre-clinical studies published by our and other groups over the past 15 years [13, 17-21, 33-36].

In all likelihood, tablet form of Panagen acts via interaction of fragmented dsDNA with immune cells resident in the intestinal lymphoid tissue. Active substance of Panagen is delivered to the upper GI tract in the form a tablet with a gastro-resistant coating where it falls apart and the substance is dissolved in the intestinal lumen. DNA fragments eventually reach mononuclear cells of Peyer's patches, lymphoid follicles of appendix and solitary follicles resulting in their activation [37]. Following activation, various immune cells of intestinal lymphoid tissue migrate into the lymph and blood circulation and reach immunocompetent organs. These immune cells stimulate proliferation and mobilization of hematopoietic progenitors or their immediate committed progeny via direct cell-cell contacts or cytokine secretion.

Similarly, dendritic cells resident in the intestinal lymphoid tissue become activated by dsDNA [33-36] and enter the lymph/bloodstream. Upon anchoring in lymphoid organs (mesenterium), these dendritic cells engulf cancer neo-antigens that become available as a tumor cell debris

Table 6 Percent of cells on day 21 following the therapy, normalized to the initial levels before the therapy. Values above 100 indicate the cell counts have increased above the initial levels

\begin{tabular}{|c|c|c|c|c|c|c|c|c|c|}
\hline \multirow{2}{*}{$\begin{array}{l}\text { Patient } \\
\text { number }\end{array}$} & \multirow{2}{*}{$\begin{array}{l}\text { Breast } \\
\text { cancer } \\
\text { stage }\end{array}$} & \multicolumn{2}{|c|}{ CD $8+$ perforin $+T$ cells } & \multicolumn{2}{|l|}{ CD123+ } & \multicolumn{2}{|l|}{ CD11+ } & \multicolumn{2}{|l|}{ CD25 + CD127- } \\
\hline & & $\begin{array}{l}\text { After the 1st } \\
\text { round of } \\
\text { chemotherapy }\end{array}$ & $\begin{array}{l}\text { After the } 3 \text { rd } \\
\text { round of } \\
\text { chemotherapy }\end{array}$ & $\begin{array}{l}\text { After the 1st } \\
\text { round of } \\
\text { chemotherapy }\end{array}$ & $\begin{array}{l}\text { After the } 3 r d \\
\text { round of } \\
\text { chemotherapy }\end{array}$ & $\begin{array}{l}\text { After the 1st } \\
\text { round of } \\
\text { chemotherapy }\end{array}$ & $\begin{array}{l}\text { After the 3rd } \\
\text { round of } \\
\text { chemotherapy }\end{array}$ & $\begin{array}{l}\text { After the 1st } \\
\text { round of } \\
\text { chemotherapy }\end{array}$ & $\begin{array}{l}\text { After the } 3 r d \\
\text { round of } \\
\text { chemotherapy }\end{array}$ \\
\hline \multicolumn{10}{|c|}{ FAC chemotherapy + Placebo } \\
\hline $02-12^{a}$ & $\| \mathrm{A}$ & 122.2 & 111.1 & 440.9 & 118.2 & 150.5 & 30.9 & 26.8 & 34.1 \\
\hline $02-07$ & IIIB & 46.7 & 105.6 & 80.0 & 176.7 & 43.8 & 200.0 & 220.8 & 54.7 \\
\hline \multicolumn{10}{|c|}{ FAC chemotherapy + Panagen } \\
\hline 02-02 & $\| A$ & 300.0 & 420.0 & 92.3 & 615.4 & 92.9 & 333.3 & 1.1 & 81.8 \\
\hline $02-10$ & $\| A$ & 178.6 & 178.6 & 543.8 & 37.5 & 666.7 & 83.3 & 120.0 & 62.0 \\
\hline $02-03$ & $\| \mathrm{A}$ & 100.0 & 23.3 & 61.4 & 59.1 & 41.1 & 41.1 & 4.5 & 116.7 \\
\hline $02-11^{a}$ & $\| B$ & 123.5 & 58.8 & 310.3 & 34.5 & 66.1 & 14.0 & 16.7 & 133.3 \\
\hline $02-15$ & IIIA & 33.3 & & 26.9 & 23.1 & 54.8 & 19.4 & 69.2 & 69.2 \\
\hline $02-05$ & IIIB & 39.4 & 106.3 & 35.3 & 220.6 & 62.7 & 178.0 & 180.0 & 160.0 \\
\hline 02-14 & $\||| B$ & - & & 153.8 & 123.1 & 97.7 & 85.2 & 127.3 & 118.2 \\
\hline $02-01$ & IIIB & 200.0 & 525.0 & 263.0 & 42.0 & 150.0 & 42.0 & 200.0 & 200.0 \\
\hline 02-08 & IIIB & 61.8 & 117.6 & 88.2 & 188.2 & 204.8 & 202.4 & 175.0 & 300.0 \\
\hline
\end{tabular}


produced by the concurrent chemotherapy. These events culminate in the development of adaptive anticancer immune response.

Clearly, in order to uncover the complexity of Panagen's anticancer activity, larger-scale clinical trials are needed. These should include massive analysis of how adaptive immunity is shaped when cytostatic drugs are given to cancer patients.

\section{Conclusions}

Disease-free survival rate $(17 \%)$ of patients with IIIB $+C$ stage receiving standard of care therapy is within the global range. Patients who additionally received Panagen demonstrate a significantly higher disease-free survival of $50 \%$. This confirms anticancer activity of Panagen.

\section{Acknowledgements}

The authors express their gratitude to Andrey Gorchakov for critical comments and translating the paper.

\section{Funding}

The LLC Panagen played crucial role in the study design and coordination. The State scientific project No. 0324-2015-0003 participated in analysis and interpretation of data and writing the manuscript. The State contracts from the Federal Targeted Program "Scientific and academic specialists for innovations in Russia", 2009-2013 of June 15th, 2009, N 02.740.11.0091, September 1st, 2010, N 14.740.11.0007, and April 29th, 2011, N 14.740.11.0922 contributed to collection, analysis, and interpretation of data.

\section{Availability of data and materials}

All data generated or analysed during this study are included in this published article.

\section{Authors' contributions}

ASP performed the analysis, interpreted the data, and drafted the manuscript. TSG carried out clinical work with patients and drafted the manuscript. EAA, EVD, KEO, VPN, and NAP performed various clinical study activities. SVS carried out clinical work with patients and participated in the study design. ERC, AAO OYL, WD, DMP, GSS, NAV, TGR, PNU, and VAR contributed to various steps of the clinical study. MAS participated in the study design and coordination. SSB conceived the study, participated in its design, coordinated and drafted the manuscript. All authors read and approved the final manuscript.

\section{Competing interests}

The authors declare that they have no competing interests.

\section{Consent for publication}

Not applicable.

\section{Ethics approval and consent to participate}

Study was approved by the Ministry of Health and Social Development of the Russian Federation (No. 47 of 03/12/2010) as well as by the local ethics committees at the Irkutsk Regional Oncology Dispensary and the Novosibirsk Municipal Hospital No 1, where clinical trials were subsequently performed. Written informed consent to participate in the study was obtained from each of the patients. Informed consent to participate specified open publication of the results presented as reports or otherwise.

\section{Author details}

${ }^{1}$ Institute of Cytology and Genetics, Siberian Branch of the Russian Academy of Sciences, 10 Lavrentieva Ave, Novosibirsk 630090, Russia. ${ }^{2}$ Novosibirsk State Medical University, Novosibirsk 630091, Russia. ${ }^{3}$ Novosibirsk State University, Novosibirsk 630090, Russia. ${ }^{4}$ Oncology Department of Municipal Hospital No 1, Novosibirsk 630047, Russia. ${ }^{5}$ Institute of Clinical Immunology, Siberian Branch of the Russian Academy of Medical Sciences, Novosibirsk 630099, Russia. ${ }^{6}$ Irkutsk State Medical Academy of Postgraduate Education,
Irkutsk 664049, Russia. ${ }^{7}$ Regional Oncology Dispensary, Irkutsk 664035, Russia. ${ }^{8}$ Clinic Department of the Central Clinical Hospital, Siberian Branch of the Russian Academy of Sciences, Novosibirsk 630090, Russia. ${ }^{9}$ CJSC "Vector-best", Koltsovo, Novosibirsk Region 630559, Russia. ${ }^{10}$ Mercer University School of Medicine, Macon, GA 31207, USA. '11 LLC "Panagen", Gorno-Altaisk 649000, Russia.

Received: 30 June 2016 Accepted: 11 August 2016

Published online: 18 August 2016

\section{References}

1. American Cancer Society. Cancer Facts and Figures 2015. Atlanta: American Cancer Society; 2015.

2. Altekruse SF, Kosary CL, Krapcho M, et al. SEER Cancer Statistics Review, 1975-2007. Bethesda: National Cancer Institute; 2010.

3. Jemal A, Center MM, DeSantis C, Ward EM. Global patterns of cancer incidence and mortality rates and trends. Cancer Epidemiol Biomarkers Prev. 2010;19(8):1893-907.

4. Cheng YC, Ueno NT. Improvement of survival and prospect of cure in patients with metastatic breast cancer. Breast Cancer. 2012;19(3):191-9.

5. Martin M, Villar A, Sole-Calvo A, Gonzalez R, Massuti B, Lizon J, Camps C, Carrato A, Casado A, Candel MT, Albanell J, Aranda J, Munarriz B, Campbell J, Diaz-Rubio E, GEICAM Group (Spanish Breast Cancer Research Group), Spain. Doxorubicin in combination with fluorouracil and cyclophosphamide (i.v. FAC regimen, day 1, 21) versus methotrexate in combination with fluorouracil and cyclophosphamide (i.v. CMF regimen, day 1,21) as adjuvant chemotherapy for operable breast cancer: a study by the GEICAM group. Ann Oncol. 2003;14(6):833-42.

6. Mackey JR, Martin M, Pienkowski T, Rolski J, Guastalla JP, Sami A, Glaspy J, Juhos E, Wardley A, Fornander T, Hainsworth J, Coleman R, Modiano MR, Vinholes J, Pinter T, Rodríguez-Lescure A, Colwell B, Whitlock P, Provencher L, Laing K, Walde D, Price C, Hugh JC, Childs BH, Bassi K, Lindsay MA, Wilson V, Rupin M, Houé V, Vogel C, TRIO/BCIRG 001 investigators. Adjuvant docetaxel, doxorubicin, and cyclophosphamide in node-positive breast cancer: 10-year follow-up of the phase 3 randomised BCIRG 001 trial. Lancet Oncol. 2013;14(1):72-80.

7. Stewart DA, Paterson AH, Ruether JD, Russell J, Craighead P, Smylie M, Mackey J. High-dose mitoxantrone-vinblastine-cyclophosphamide and autologous stem cell transplantation for stage III breast cancer: final results of a prospective multicentre study. Ann Oncol. 2005;16(9):1463-8.

8. Ang PT, Buzdar AU, Smith TL, Kau S, Hortobagyi GN. Analysis of dose intensity in doxorubicin-containing adjuvant chemotherapy in stage II and III breast carcinoma. J Clin Oncol. 1989;7(11):1677-84.

9. Perez EA. Adjuvant therapy approaches to breast cancer: should taxanes be incorporated? Curr Oncol Rep. 2003;5(1):66-71.

10. Gonzalez-Angulo AM, Walters R, Broglio K, Frye DK, Strom EA, Theriault RL, Booser DJ, Valero V, Buzdar AU, Hortobagyi GN. Using response to primary chemotherapy to select postoperative therapy: long-term results from a prospective phase II trial in locally advanced primary breast cancer. Clin Breast Cancer. 2008;8(6):516-21.

11. Kuraparthy S, Reddy KM, Yadagiri LA, Yutla M, Venkata PB, Kadainti SV, Reddy RP. Epidemiology and patterns of care for invasive breast carcinoma at a community hospital in Southern India. World J Surg Oncol. 2007;5:56.

12. Hortobagyi GN, Ames FC, Buzdar AU, Kau SW, McNeese MD, Paulus D, Hug V, Holmes FA, Romsdahl MM, Fraschini G, et al. Management of stage III primary breast cancer with primary chemotherapy, surgery, and radiation therapy. Cancer. 1988;62(12):2507-16

13. Proskurina AS, Gvozdeva TS, Alyamkina EA, Dolgova EV, Orishchenko KE, Nikolin VP, Popova NA, Sidorov SV, Chernykh ER, Ostanin AA, Leplina OY, Dvornichenko W, Ponomarenko DM, Soldatova GS, Varaksin NA, Ryabicheva TG, Zagrebelniy SN, Rogachev VA, Bogachev SS, Shurdov MA. Results of multicenter double-blind placebo-controlled phase II clinical trial of Panagen preparation to evaluate its leukostimulatory activity and formation of the adaptive immune response in patients with stage II-IV breast cancer. BMC Cancer. 2015:15(1):122.

14. Ishii KJ, Suzuki K, Coban C, Takeshita F, Itoh Y, Matoba H, et al. Genomic DNA released by dying cells induces the maturation of APCs. J Immunol. 2001;167(5):2602-7.

15. Klinman DM. Immunotherapeutic uses of $\mathrm{CpG}$ oligodeoxynucleotides. Nat Rev Immunol. 2004:4:249-58. 
16. Krieg AM. Development of TLR9 agonists for cancer therapy. J Clin Invest. 2007;117(5):1184-94.

17. Alyamkina EA, Dolgova EV, Likhacheva AS, Rogachev VA, Sebeleva TE, Nikolin VP, Popova NA, Kiseleva EV, Orishchenko KE, Sakhno LV, Gel'fgat EL, Ostanin AA, Chernykh ER, Zagrebelniy SN, Bogachev SS, Shurdov MA. Exogenous allogenic fragmented double-stranded DNA is internalized into human dendritic cells and enhances their allostimulatory activity. Cell Immunol. 2010;262:120-6.

18. Dolgova EV, Efremov YR, Orishchenko KE, Andrushkevich OM, Alyamkina EA, Proskurina AS, Bayborodin SI, Nikolin VP, Popova NA, Chernykh ER, Ostanin AA, Taranov OS, Omigov W, Minkevich AM, Rogachev VA, Bogachev SS, Shurdov MA. Delivery and processing of exogenous double-stranded DNA in mouse CD34+ hematopoietic progenitor cells and their cell cycle changes upon combined treatment with cyclophosphamide and double-stranded DNA. Gene. 2013;528(2):74-83.

19. Dolgova EV, Alyamkina EA, Efremov YR, Nikolin VP, Popova NA, Tyrinova TV, Kozel AV, Minkevich AM, Andrushkevich OM, Zavyalov EL, Romaschenko AV, Bayborodin SI, Taranov OS, Omigov W, Shevela EY, Stupak W, Mishinov SV, Rogachev VA, Proskurina AS, Mayorov VI, Shurdov MA, Ostanin AA, Chernykh ER, Bogachev SS. Identification of cancer stem cells and a strategy for their elimination. Cancer Biol Ther. 2014;15(10):1378-94.

20. Alyamkina EA, Nikolin VP, Popova NA, Dolgova EV, Proskurina AS, Orishchenko KE, Efremov YR, Chernykh ER, Ostanin AA, Sidorov SV, Ponomarenko DM, Zagrebelniy SN, Bogachev SS, Shurdov MA. A strategy of tumor treatment in mice with doxorubicin-cyclophosphamide combination based on dendritic cell activation by human double-stranded DNA preparation. Genet Vaccines Ther. 2010;8(1):7. http://www.gvt-journal.com/content/8/1/7.

21. Alyamkina EA, Leplina OY, Ostanin AA, Chernykh ER, Nikolin VP, Popova NA, Proskurina AS, Gvozdeva TS, Dolgova EV, Orishchenko KE, Rogachev VA, Sidorov SV, Varaksin NA, Ryabicheva TG, Bogachev SS, Shurdov MA. Effects of human exogenous DNA on production of perforin-containing CD8+ cytotoxic lymphocytes in laboratory setting and clinical practice. Cell Immunol. 2012;276:59-66.

22. Wittig B, Schmidt M, Scheithauer W, Schmoll HJ. MGN1703, an immunomodulator and toll-like receptor 9 (TLR-9) agonist: from bench to bedside. Crit Rev Oncol Hematol. 2015;94(1):31-44.

23. Scheiermann J, Klinman DM. Clinical evaluation of CpG oligonucleotides as adjuvants for vaccines targeting infectious diseases and cancer. Vaccine. 2014;32(48):6377-89

24. Balabram D, Turra CM, Gobbi H. Sunvival of patients with operable breast cancer (Stages I-III) at a Brazilian public hospital-a closer look into cause-specific mortality. BMC Cancer. 2013;13:434.

25. Leone JP, Leone J, Vallejo CT, Pérez JE, Romero AO, Machiavelli MR, Romero Acuña L, Domínguez ME, Langui M, Fasce HM, Leone BA, Ortiz E, Iturbe J, Zwenger AO. Sixteen years follow-up results of a randomized phase II trial of neoadjuvant fluorouracil, doxorubicin, and cyclophosphamide (FAC) compared with cyclophosphamide, methotrexate, and 5-fluorouracil (CMF) in stage III breast cancer: GOCS experience. Breast Cancer Res Treat. 2014;143(2):313-23.

26. Bilgrami S, Bona RD, Edwards RL, Li Z, Naqvi B, Shaikh A, Furlong F, Fox J, Clive J, Tutschka PJ. Dexamethasone, paclitaxel, etoposide, cyclophosphamide (d-TEC) and G-CSF for stem cell mobilisation in multiple myeloma. Bone Marrow Transplant. 2001;28(2):137-43.

27. Klein JL, Hamm C, Dansey RD, Karanes C, Abella E, Cassells L, Peters WP, Baynes RD. High-dose chemotherapy and CD34-selected peripheral blood progenitor cell transplantation for patients with breast cancer metastatic to bone and/or bone marrow. Bone Marrow Transplant. 2001;28(11):1023-9.

28. Statkute L, Verda L, Oyama Y, Traynor A, Villa M, Shook T, Clifton R, Jovanovic B, Satkus J, Loh Y, Quigley K, Yaung K, Gonda E, Krosnjar N, Spahovic D, Burt RK. Mobilization, harvesting and selection of peripheral blood stem cells in patients with autoimmune diseases undergoing autologous hematopoietic stem cell transplantation. Bone Marrow Transplant. 2007;39(6):317-29.

29. Salem ML, El-Naggar SA, Cole DJ. Cyclophosphamide induces bone marrow to yield higher numbers of precursor dendritic cells in vitro capable of functional antigen presentation to T cells in vivo. Cell Immunol. 2010;261(2):134-43.

30. Nakahara T, Uchi H, Lesokhin AM, Avogadri F, Rizzuto GA, HirschhornCymerman D, et al. Cyclophosphamide enhances immunity by modulating the balance of dendritic cell subsets in lymphoid organs. Blood. 2010;115(22):4384-92.
31. Zhao J, Cao Y, Lei Z, Yang Z, Zhang B, Huang B. Selective depletion of CD4 + CD25 + Foxp3+ regulatory T cells by low-dose cyclophosphamide is explained by reduced intracellular ATP levels. Cancer Res. 2010;70(12):4850-8.

32. Ouyang Z, Wu H, Li L, Luo Y, Li X, Huang G. Regulatory T cells in the immunotherapy of melanoma. Tumour Biol. 2016;37(1):77-85.

33. Doerfler W, Orend G, Schubbert R, Fechteler K, Heller H, Wilgenbus P, Schröer $J$. On the insertion of foreign DNA into mammalian genomes: mechanism and consequences. Gene. 1995;157(1-2):241-5.

34. Doerfler W, Remus R, Müller K, Heller H, Hohlweg U, Schubbert R. The fate of foreign DNA in mammalian cells and organisms. Dev Biol (Basel). 2001;106:89-97. discussion 143-60.

35. Schubbert R, Lettmann C, Doerfler W. Ingested foreign (phage M13) DNA survives transiently in the gastrointestinal tract and enters the bloodstream of mice. Mol Gen Genet. 1994;242(5):495-504.

36. Schubbert R, Renz D, Schmitz B, Doerfler W. Foreign (M13) DNA ingested by mice reaches peripheral leukocytes, spleen, and liver via the intestinal wall mucosa and can be covalently linked to mouse DNA. Proc Natl Acad Sci U S A. 1997;94(3):961-6.

37. Orishchenko KE, Ryzhikova SL, Druzhinina YG, Ryabicheva TG, Varaksin NA, Alyamkina EA, Dolgova EV, Rogachev VA, Proskurina AS, Nikolin VP, Popova NA Strunov AA, Kiseleva EV, Leplina OY, Ostanin AA, Chernykh ER, Sidorov SV, Mayorov VI, Bogachev SS, Shurdov MA. Effect of human double-stranded DNA preparation on the production of cytokines by dendritic cells and peripheral blood cells from relatively healthy donors. Cancer Ther. 2013;8:191-205.

38. Laohavinij S, Ruikchuchit K, Maneechavakajorn J. Survival and prognostic factors of stage I-III breast cancer. J Med Assoc Thai. 2013;96 Suppl 3:S23-34.

39. Justo N, Wilking N, Jönsson B, Luciani S, Cazap E. A review of breast cancer care and outcomes in Latin America. Oncologist. 2013;18(3):248-56.

\section{Submit your next manuscript to BioMed Central and we will help you at every step:}

- We accept pre-submission inquiries

- Our selector tool helps you to find the most relevant journal

- We provide round the clock customer support

- Convenient online submission

- Thorough peer review

- Inclusion in PubMed and all major indexing services

- Maximum visibility for your research

Submit your manuscript at www.biomedcentral.com/submit
Ciomed Central 